\title{
DEÁK JÓZSEF
}

\section{A rendészettudomány és a határőrgondolatok találkozása - múlt nélkül nincs jövő}

A pécsi határörök által 2001-ben útnak indított tudományos konferenciasorozat $^{1}$ húsz kötete bőven több mint félezer (egészen pontosan: hatszázhetvenhat) alkotást és ki tudja, mennyi szakmai ${ }^{2}$ és tudományos gondolatot közvetített a rendészetnek ${ }^{3}$ és a rendészettudománynak. ${ }^{4}$ Emellett hány örömteli találkozást ajándékozott a részt vevő határőröknek és a társszervekben együttműködő kollégáiknak, így különösen a rendőröknek, a bevándorlási és állampolgársági hivatalok, a katasztrófavédelem, a büntetés-végrehajtás, a nemzetbiztonsági szolgálatok ${ }^{5}$ más együttmüködő minisztériumok, egyéb állami és civil szervek/szervezetek hazai és külföldi meghívott kutatóinak, munkatársainak. A konferenciaszervezők ügy iránti elkötelezettsége, lelkiismeretes állhatatossága, ötletgazdagsága, az új iránti fogékonysága, a rendészettudomány mủvelésébe, gazdagításába, vetett hite örökíti át és teszi köz-

1 Zámbó Péter: Epilógus. Határőrnapi konferenciák a szolgálat érdekében, Szent László szellemében. In: Gaál Gyula - Hautzinger Zoltán (szerk.): Pécsi Határőr Tudományos Közlemények. Magyar Hadtudományi Társaság Határőr Szakosztály Pécsi Szakcsoportja, Pécs, 2004, 278-279. o.

http://www.pecshor.hu/periodika/2004/Zambo.pdf

2 Vö. „A Pécsi Határőr Tudományos Közlemények jelen VII. száma is bizonyítja, hogy az elméleti felkészülés olyan biztos háttért ad, mely a célba vett integrációt minden bizonnyal sikerre viszi majd." Korinek László: Beköszöntő. In: Gaál Gyula - Hautzinger Zoltán (szerk.): Pécsi Határőr Tudományos Közlemények. Magyar Hadtudományi Társaság Határőr Szakosztály Pécsi Szakcsoportja, Pécs, 2007, 1-2. o. http://www.pecshor.hu/periodika/2007/VII/bekoszonto.pdf

3 Finszter Géza: A rendészet jogi természete, rendvédelem - honvédelem. In: Gaál Gyula - Hautzinger Zoltán (szerk.): Pécsi Határőr Tudományos Közlemények. Magyar Hadtudományi Társaság Határőr Szakosztály Pécsi Szakcsoportja, Pécs, 2002, 13-26. o. http://www.pecshor.hu/periodika/2002/finszter.pdf ; Janza Frigyes: A rendészeti karrier rendszer. In: Gaál Gyula - Hautzinger Zoltán (szerk.): Pécsi Határőr Tudományos Közlemények. Magyar Hadtudományi Társaság Határőr Szakosztály Pécsi Szakcsoportja, Pécs, 2008, 107-132. o. http://www.pecshor.hu/periodika/2008/janza.pdf

4 Virányi Gergely: Gondolatok a rendészettudományhoz In: Gaál Gyula - Hautzinger Zoltán (szerk.): Pécsi Határőr Tudományos Közlemények Magyar Hadtudományi Társaság Határőr Szakosztály Pécsi Szakcsoportja, Pécs, 2002, 34-68. o. http://www.pecshor.hu/periodika/2002/viranyi.pdf

5 Deák József: Szigorúan titkos-e a jó teljesítmény?! In: Dobák Imre - Hautzinger Zoltán (szerk.): Szakmaiság, szerénység, szorgalom. Ünnepi kötet a 65 éves Boda József tiszteletére. Dialóg Campus Kiadó-Nordex Kft., Budapest, 2018, 165-176. o.; Deák József: Az állambiztonsági propaganda, annak kialakulása és fejlődése - nemzetbiztonság és civil kapcsolatok. Társadalom és honvédelem, 2013/3-4., 408-417. o.; Deák József: Az állambiztonsági propagandától a nemzetbiztonságig - a Belügyi Szemlében megjelentek tükrében. Rendvédelem, 2013/3., 15-22. o. 
kinccsé napjainkig - talán nem is mindig tudatosan - az egykori határőrség szervezeti kultúrájának évtizedeken át kikristályosodott értékeit. Ezek élednek újjá és próbálnak utat törni maguknak az integrált szervezetben 2008-tól.

\section{A pécsi rendészeti alkotómúhely}

Nyolc taggal, 2000. május 17-én alakult meg a Magyar Hadtudományi Társaság (MHTT) Határör Szakosztályának Pécsi Szakcsoportja, amely a határörség ünnepnapja (június 27. Szent László-nap) alkalmából 2001-ben rendezte meg mérföldkőnek számító első szakmai tudományos tanácskozását $A$ határellenőrzés múltja, jelene és jövője címmel. A tapasztalatcsere kedvező fogadtatását hagyományteremtő szándékkal követő, a Határörség és rendészet elnevezésü tanácskozáson elhangzottak már tanulmánykötetben jelentek meg, Pécsi Határör Tudományos Közlemények címmel, 2002-ben. E tudományszervező tevékenységbe 2004-től bekapcsolódott az újonnan létrehozott, Magyar Rendészettudományi Társaság (MRTT) Határrendészeti Tagozatának Pécsi Szakcsoportja, mert a hadtudományi szakcsoport tagjai aktív kezdeményezői és alapítói is voltak az ekkor, május 24-én, Budapesten megalakult MRTT-nek. ${ }^{6}$

Az MHTT és határőr szakosztálya létrehozatalának huszonöt évvel korábbi körülményeire és az azóta eltelt időszak alatt végzett tudományos munkásságra emlékező ünnepi közgyülésen a szakosztályok vezetői közül Fórizs Sándor nyugállományú rendőr dandártábornok a határőr szakosztály munkájáról tartott rövid hozzászólásában ki is emelte, hogy a 2012-ben a Magyar Felsőoktatási Akkreditációs Bizottság által is elismert rendészettudománnyal a hadtudománynak széles közös sávja van és lesz, például az illegális migráció, vagy a terrorizmus elleni fellépés területén. ${ }^{7}$

6 Gaál Gyula: Tizenöt kötet a rendészettudomány szolgálatában. In: Gaál Gyula - Hautzinger Zoltán (szerk.): Rendészettudományi gondolatok. Írások a Magyar Rendészettudományi Társaság megalapításának egy évtizedes jubileuma alkalmából. MRTT, Budapest, 2014, 209. o.

7 Fórizs Sándor: Gondolatok hadtudomány és a rendészettudomány jövőbeni együttműködésének fontosságáról. Hadtudomány, 2016/1-2., 123. o. http://mhtt.eu/hadtudomany/2016/1-2/Hadtudomany_ 2016_1-2_netre.124-125.pdf ; Deák József: Negyedszázados fennállásukat ünneplő tudományos társaságok. Nemzetbiztonsági Szemle, 2015/4., 105. o.; „A XXI. század - határozott kriminálpolitikáján alapuló - európai rendőrségének a lokális és a globális biztonság kérdéseire egyaránt következetes válaszokat kell adnia. Fel kell venni a harcot a terrorizmus, a szervezett bünözés és az illegális bevándorlás ellen. A szabadságjogokat, és az emberi jogokat, ellenfeleikkel szemben szükséges, és meg is kell tudnunk védeni.” Kovács István: Prostitúció, és prohibíció a mai Magyarországon: avagy miért nem sikerül a rendőrségnek a szocializmust levetkőzni a XXI. században. Létünk, 2018/2., 17. o. 
Az MTA Gazdaság- és Jogtudományok Osztálya 2007. június 6-án hozott döntése alapján, szeptember 5-én az MTA köztestületi tagjainak részvételével egy évre megválasztották a Rendészettudományi Bizottság elnökét, elnökhelyettesét, titkárát és tagjait. ${ }^{8}$ (2002-ben, Janza Frigyes, a rendészeti vezetöképzésért felelős intézmény oktatási igazgatója felkérésére Szabó András akadémikus kidolgozta a rendészettudomány tartalmát, differencia specificáit. 2004-ben megalakult az MRTT. A társaság tudományos minősítéssel, fokozattal, címmel rendelkezö tagjai 2007. január 30-án munkacsoportba tömörültek. A csoport által elfogadott szándéknyilatkozat javaslat formájában eljutott a Magyar Tudományos Akadémia elnökének, fötitkárának és az MTA IX. Osztály elnökének. (A javaslatot aláíró negyvennégy tudományos címmel bíró tag több mint harmada határőr tiszt volt.)

Ennek első pontjában javasolták, hogy az MTA, „Szervezeti és Müködési Szabályzatának ez évi Közgyülési módositásával, teremtse meg a feltételét, hogy a IX. Osztályon belül megalakuljon a Rendészettudományi Bizottság”". Később, az MTA karcsúsításának keretében a bizottság albizottsággá változott.

Ez logikusan következik abból, hogy napjainkban a rendészettudomány ${ }^{10}$ egy olyan interdiszciplináris tudomány, amely a közigazgatás-tudomány gyökereként, a feudális rendőrállam módszertanából eredő modern rendészeti igazgatást mint más társadalomtudományoktól elhatárolható alrendszert vizsgálja. Fontos azonban megjegyezni, hogy a rendészet sem a múltban, sem napjainkban nem szorítkozik kizárólag a rendőrség müködésére. ${ }^{11}$

A Pécsi Határőr Tudományos Közlemények kiadványt elsődlegesen azzal a céllal indították útjára, hogy a pécsi konferenciák előadásai, a kapcsolódó hozzászólások tanulmányszerü változatai egységes szerkesztésben eljuthas-

\footnotetext{
8 Rendészettudományi Bizottság alakult. http://netrix.mta.nsd.sztaki.hu/mta_hirei/rendeszettudomanyibizottsag-alakult-47371/

9 Janza Frigyes, MRTT-fötitkár aláírásával készült Feljegyzés az MRTT tudományos minösitéssel, fokozattal, címmel rendelkezö tagjainak 2007. január 30-i munkacsoport üléséröl. MRTT-archívum.

10 Virányi Gergely: Aktualizált gondolatok a rendészettudományhoz tükrében In: Gaál Gyula Hautzinger Zoltán (szerk.): A rendészettudomány határkövei. Tanulmányok a Pécsi Határőr Tudományos Közlemények első évtizedéből. Magyar Hadtudományi Társaság Határőr Szakosztály Pécsi Szakcsoportja, Pécs, 2012, 11-38. o. http://www.pecshor.hu/periodika/hatarkovek/viranyi.pdf

11 Hautzinger Zoltán: A kriminalisztika és a rendészettudomány határterületei. Magyar Rendészet, 2015/1., 14. o.; Deák, József: The Police, then Interior Review for the forming of the science of law enforcement; from its beginning to the change of the political system. West Bohemian Historical Review, vol. 4, no. 2, Pilsen-Hamburg, 2014, pp. 237-250. https://otik.uk.zcu.cz/bitstream/11025/ 15549/1/Deak.pdf ; Deák József: A rendészettudomány kialakulása és fejlődése a Belügyi Szemle (1953-2013) tükrében. In: Gaál Gyula - Hautzinger Zoltán (szerk.): Pécsi Határőr Tudományos Közlemények. Magyar Hadtudományi Társaság Határőr Szakosztály Pécsi Szakcsoportja, Pécs, 2014, 355-359. o.
} 
sanak azokhoz, akik nem voltak ott a rendezvényen, megjelenési lehetőséget teremtve egyúttal a rendvédelmi szervek szakmai tevékenységéhez kapcsolódó tudományágak (hadtudomány, rendészettudomány, jogtudomány, illetve egyéb társadalom- vagy természettudomány) müvelőinek. ${ }^{12}$

A közlemények szerkesztöinek nem volt céljuk ugyan, hogy köteteik a rendészeti folyóiratok, a Rendészeti (Belügyi) Szemle vagy a Magyar Rendészet versenytársai legyenek, de tudományos munkásságukat mindenképp iránymutatónak, példaadónak tartották. ${ }^{13}$

A rendészeti kommunikáció ${ }^{14}$ néhány sajátossága ${ }^{15}$ ismeretében megállapítható, hogy a speciális rendészeti tevékenységek esetében mindenképp fontos és szükséges egy vagy több olyan szervezeten belüli, akár miniszteriális szintủ kiadvány, orgánum, amely erősíti a szervezet kohézióját, valamint a szervezeti kultúra egyik színtereként funkcionál. ${ }^{16}$

\section{Hagyományőrzés, -ápolás, -továbbörökítés}

2008. január 1-jével került sor a határőrség és a rendőrség integrációjára. Varga János, a Magyar Rendészettudományi Társaság Határrendészeti Tagozatának elnöke a rendőrség újonnan létrejött határrendészeti szolgálati ágának vezetőihez írt levelében az új körülmények között fontosnak tartotta kiemelni, hogy a tagozat „Hozzá szeretne járulni a határörség értékeinek és tradiciójának megóvásához és átviteléhez, a határrendészeti szolgálati ág felépitéséhez,

12 Hautzinger Zoltán: Tíz kötet a rendészettudomány szolgálatában. Rendészeti Szemle, 2010/2., 127128. o.

13 Deák József: A Belügyi Szemle a közpolitika szolgálatában (1953-1990). Hadtudományi Szemle, 2017/1., 375-390. o. http://uni-nke.hu/downloads/kutatas/folyoiratok/hadtudomanyi_szemle/szamok /2017/2017_1/17_1_alt_deak.pdf ; Deák József: A Belügyi Szemle közpolitikai, rendészetelméleti és szerkezeti fejlődése a rendszerváltásig. Hadtudományi Szemle, 2017/2., 339-355. o. http://uninke.hu/downloads/kutatas/folyoiratok/hadtudomanyi_szemle/szamok/2017/2017_2/17_2 alt_deak.pdf.

14 Deák József: A Belügyi Szemle Tájékoztatójában a médiával kapcsolatban megjelent anyagok (19631972). Magyar Rendészet, 2014/2., 127-137. o.

15 Deák József: Belügyi Szemle a sajtónyilvánosságért 1953-1990. In: Gaál Gyula - Hautzinger Zoltán (szerk.): Szent Lászlótól a modernkori magyar rendészettudományig. Magyar Hadtudományi Társaság Határőr Szakosztály Pécsi Szakcsoport, Pécs, 2017, 225-231. o.

16 Deák József: A polgári magyar állam rendvédelmi sajtója 1867-1944. In: Parádi Ákos (szerk.): Ünnepi tanulmányok Parádi József 65. születésnapja tiszteletére. Szemere Bertalan Magyar Rendvédelem-történeti Tudományos Társaság, Budapest, 2015, 71. o.; Vö. „Az államigazgatásban, rendvédelmi területen dolgozókkal szemben ezért is fogalmazódik meg többletkövetelményként, hogy egységes hivatásetikai elvárások szerint végezzék a munkájukat...” Kovács István: Az üzletszerü kéjelgéssel kapcsolatos rendőri visszaélések etikai vonatkozásai. Belügyi Szemle, 2015/4., 102. o. 
müködtetéséhez, a folyamatosság megőrzéséhez, a határrendészek identitásának és önbecsülésének újjáépitéséhez, gondozásához"'" . A hagyományos, pécsi, Szent László-napi konferenciáról akkor megjelenő kötet köszöntőjében az országos rendőrfőkkapitány, Bencze József annak a reményének adott hangot, hogy „Az integrált szervezetü rendörség, a korábbi rendör és határör szervezet legértékesebb hagyományait egyesitve, képes lesz megfelelni a XXI. század századi európai rendészeti szervekkel szemben támasztott követelményrendszernek"18.

Még korábban, ugyanazon év tavaszán a fökapitány az integrált szervezet doktoranduszfórumán meg is jegyezte - a megjelentek túlnyomó részének határőrtiszt mivoltára utalva -, a helyzet jól példázza, hogy a kutatás, a tudományos tevékenység, és a tanulmányok támogatásában is van mit tanulni a határörségtől!

Vannak, akik a nyugdíjkorhatárt elérve sem vonultak vissza a tudományos munkától; hetvenévesen is a rendőrségi képzés segítésében vesznek részt, határőroktatási tapasztalataik ${ }^{19}$ átadásával, mint például Beregnyei József, Kónya József, egykori határőr tanszékvezető, Szép Zoltán, Zsigovits László.

Az e kötetben szereplő írásában Janza Frigyes is amellett szállt síkra, hogy a rendészeti rendszerek hivatásos állományával összefüggésben nagyobb társadalmi érdek füződik egy értékeket hordozó és értékalapú kiválasztással müködtethető testület, mintsem az eseti munkavállalók sokaságával feltöltött, csak a konkrét munkavégzést díjazó tagsághoz. ${ }^{20}$

A határőrségi hagyományőrzés a pécsi közleményekéhez hasonlóan szép, a vizsgált korszakában lényegében egybeeső, alig idősebb, immár negyedszázadra visszatekintő példája, a Nemzeti Közszolgálati Egyetem határrendé-

17 Varga János: A Magyar Rendészettudományi Társaság Határrendészeti Tagozata első évtizedének mérlege. In: Gaál Gyula - Hautzinger Zoltán (szerk.): Rendészettudományi gondolatok. Magyar Rendészettudományi Társaság, Budapest, 2014, 20-203. o.

18 Bencze József: Beköszöntő. In: Gaál Gyula - Hautzinger Zoltán (szerk.): Pécsi Határőr Tudományos Közlemények. Magyar Hadtudományi Társaság Határőr Szakosztály Pécsi Szakcsoportja, Pécs, 2008, 3. o.; Vö. „A globalizációnak köszönhetően az államigazgatásban dolgozók rákényszerülnek arra, hogy a rohanó világgal lépést tartva mindennapi életüket úgy szervezzék, állami intézményeket úgy vezessenek, hogy azok a néptől kapott legitim állami hatalom monopóliumával, társadalmi rendeltetésüket maximálisan elláthassák." Kovács István: Vezetési funkciók egy helyi rendvédelmi szerv életében. Ellenőrzés, mint a kiadott szabályok, és utasítások betartásának (kontroll)feladata. Államtudományi Mühelytanulmányok, 2017/21., 3. o.

19 Virányi Gergely: A rendészeti felsőoktatás modernizációja. In: Gaál Gyula - Hautzinger Zoltán (szerk.): Pécsi Határőr Tudományos Közlemények, Pécs, 2006, 39-46. o.

20 Janza Frigyes: i. m. 108. o. 
szeti tanszékének müködése ${ }^{21}$, amint az a Közszolgálati képzés kihívásai a határrendészeti tisztképzés tükrében címü, 2017 tavaszán megrendezett konferencia tanulmánykötetéből is kiderül.

Ez a Pécsi Határőr Tudományos Közlemények eddig megjelent köteteihez hasonló céllal, szellemiséggel, tematikával készült a Határőrizeti és testületi modernizációtól a mai népvándorlás határrendészeti kezeléséig: a határrendészeti tisztképzés negyedszázada címmel. A határör-közlemények tudományos publikációiban is taglalt, egyebek közt a határrendészet mindennapjainak kihívásait, nehézségeit, a „határőrminőség”-et, a 2008-as integráció keserveit saját élményeken át, azaz a pécsi kötetek tanulmányainál megszokottnál talán plasztikusabban bemutató kiadvány Varga János rendőr ezredes, tanszékvezető szerkesztésében jelent meg.

A tudományos közlemények egyik szerkesztöjének, Gaál Gyulának tulajdonítják ezt a gondolatot: „Nekünk, határöröknek, nincs okunk megretteni a bizonytalan jövötöl, annak ismeretlen kihívásaitól, mert csak a feladatunk módosul! Felkészültségünkbe, határörségi szakmai tapasztalatainkba eddig is beletartozó módon, az új szervezetben az új feladatokat is a tölünk eddig elvárt, megszokott formában; szakszerïen, lelkiismeretesen fogjuk teljesiteni!"

Egyéni kudarcát fordította szerencsévé a negyedszázados tisztképzés másik tanítványa is: „A jelentkezési lapot - a mai napig nem tudom miért - az RTF-re töltöttem ki, bünügyi szakra. A felvételi vizsgán azonban egyetlen pont hiján lemaradtam a legjobbak mögött, ezért sajnálattal értesitettek, hogy nem vettek fel. Családi kupaktanács után döntöttem; besétálok a mosonmagyaróvári rendörkapitányságra és beállok rendörnek. Egy kora nyári reggelen éppen indultam a vasútállomásra (hogy rendör legyek), amikor a postás megállított és a kezembe nyomott egy nekem címzett ajánlott levelet a Rendörtiszti Föiskoláról. Új tanszék indul a föiskolán és tekintettel arra, hogy határterületi lakos vagyok (Honnan tudtam volna még, hogy a határörségnél mit jelent lakhelyem neve: »Hegyeshalom«...?), ha elfogadom az

\footnotetext{
21 Kovács Gábor: Hogyan tovább? A Határrendész tisztképzés reformja a határőrség-rendőrség szervezeti integrációját követően. Határrendészeti Tanulmányok, 2008/1., 4-22. o.; Kovács Gábor: A Nemzeti Közszolgálati Egyetem alapképzésben végzett rendőrtisztekkel szemben támasztott követelmények változásai. In: Gaál Gyula - Hautzinger Zoltán (szerk.): A határrendészettől a rendészettudományig. Magyar Hadtudományi Társaság Határőr Szakosztály Pécsi Szakcsoportja, Pécs, 2016, 263-268. o. [Pécsi Határör Tudományos Közlemények, XVII.] http://pecshor.hu/periodika/XVII/kovacs.pdf ; Balla József: Felsőfokú szakirányú képzés a Határrendészeti Tanszéken 2005-ben és 2015-ben. In: Varga János (szerk.): A határrendészeti tisztképzés negyedszázada. Dialóg Campus Kiadó, Budapest, 2017, 47 54. o.
} 
ajánlatot, megkezdhetem tanulmányaimat az új szakon, elökészitöként Körmenden egy év felkészitéssel." 22

A határrendész tanszék sikerrel hagyományozta át hallgatóinak a folyamatos tanulás fontosságát is, ami nem fejeződhet be a diploma átvételével! „Úgy gondolom, az élethosszig való tanulás alapkövetelmény a rendöri hivatásban! Ezért adtam be jelentkezésemet 2015-ben a Közszolgálati Egyetem Rendészettudományi Kar Rendészeti vezetö mesterszakára. Ennek elvégzésével célom, munkám magasabb színvonalon történö ellátása, hogy még napakészebben állhassak a jövöbeli kihivásai elé." ${ }^{23}$

Az egyéni képességek, szorgalom mellett a bajtársiasság, egymás segítése legalább ilyen fontos, ezek kialakítása már a szakon elkezdődik. „Határrendész hallgatóként ugyancsak jó érzéssel töltött el bennünket, hogy a felsöbb évfolyamos hallgatók is rendkivül korrekt, kollegiális kapcsolatot alakitottak ki velünk. Hozzájuk bármikor fordulhattunk tanácsért, segitségért, igy nagyon pozitív benyomás alakult ki róluk. Közülük többen már a szorgalmi idöszak elsö napjaiban megszólitottak bennünket, öszintén kérdeztek problémáink felöl, éreztetve; rájuk mindig számithatunk. Támogatásuk már beilleszkedésünk során azt az érzést erösitette bennünk, hogy e tanszék hallgatóiként szinte egy nagy család részei lettünk. Így sok felsöbb éves határrendész hallgatóra néztünk fel szorgalma, hozzáállása vagy éppen korrektsége, áldozatos segítökészsége miatt. Ráadásul az akkori végzösök közül többen, már néhány év hivatásos szolgálat után kerültek hallgatónak a föiskolára, így gyakorlati tapasztalataikkal, ismereteikkel is segitették tanulmányainkat, felkészülésünket. Elsösként jó volt látni a végzösök céltudatosságát, lendületes készülését a záróvizsgákra, leendö szolgálati helyeikre. Ez nekünk is eröt adott a mindennapokban." ${ }^{24}$

Nemcsak a szolgálatból kerültek hallgatók a határrendészeti tanszékre, hanem külföldröl is.

„A moszkvai határör parancsnoki föiskoláról, az ott eltöltött időszakról egy valós történeteken alapuló, nagyobb lélegzetü, kalandokkal és európai, magyar ember számára nehezen elképzelhetö sztorikkal teli regényt lehetne

22 Vájlok László: Önvallomás - végigkísérve negyedszázadot, köszönetet mondva sok-sok embernek. In: Varga János (szerk.): A határrendészeti tisztképzés negyedszázada. Budapest, 2017, 186. o.; Beregnyei József: Az RTF határrendész előkészítő képzés Körmenden. In: Varga János (szerk.): A határrendészeti tisztképzés negyedszázada. Dialóg Campus Kiadó, Budapest, 2017, 74. o.

23 Hegedüs Dániel: Alapkiképzéstől napjainkig. In: Varga János (szerk.): A határrendészeti tisztképzés negyedszázada. Dialóg Campus Kiadó, Budapest, 2017, 193. o.

24 Gáspár Gyula: Visszatekintés másfél évtizedre. In: Varga János (szerk.): A határrendészeti tisztképzés negyedszázada. Dialóg Campus Kiadó, Budapest, 2017, 195. o. 
irni, mintahogyan többen el is kezdtük annak késöbbi alapjaként szánt naplónkat. A mostani tanulmány adta szük keretekre tekintettel viszont mindenképp fontosnak tartom a külföldi tanintézetröl kihangsúlyozni: a határör tisztek szakmai legjobbjai oktattak bennünket, és még az alakiasság is müvészi szinten valósult meg. "'25

Mindezek a visszaemlékezések megerősítik, hogy „A Rendörtiszti Föiskola, majd a Nemzeti Közszolgálati Egyetem kellö toleranciával engedett teret a szak, majd a szakirány specifikus jellegének, a tanszék önálló arculatának kialakitásához és tudatos ápolásához "’26.

A határrendészeti átalakulásokat és hagyományokat egymásra hatásukban, egységben vizsgálta Fórizs Sándor. ${ }^{27}$

\section{A kötetek eszmeiségének müködése a gyakorlatban - legfrissebb adalékok}

A napjainkig elő-előbukkanó határőr szervezeti kultúra továbbélő elemeit érzékletesen sorakoztatta fel egy legutóbbi szakmai-tudományos tanácskozás. Az RTK határrendészeti tanszéke 2018-ban a tudomány ünnepe alkalmából november végén rendezte meg az Egy évtized a rendörség kötelékében címü konferenciáját a schengeni egyezményekhez történő teljes jogú csatlakozás ${ }^{28}$ és a határőrség rendőrségbe integrálása évtizedének áttekintésére.

A tanácskozás köszöntöjét Kovács Gábor, az NKE oktatási rektorhelyettese azzal kezdte, hogy a határ örizete nagyon fontos hivatás, ami csak szív-

25 Éberhardt Gábor: A határrendészeti tisztképzés elmúlt negyedszázada. Múlt, jelen, jövő. In: Varga János (szerk.): A határrendészeti tisztképzés negyedszázada. Dialóg Campus Kiadó, Budapest, 2017, 210. o.; Deák József: Az Oroszországi Föderáció Szövetségi Biztonsági Szolgálata határőrtiszt képzésének történetéből, módszereiből napjainkig. In: Deák József - Gaál Gyula - Sallai János (szerk.): A toll sokszor erősebb, mint a kard. Rendészettudományi tanulmányok Prof. Dr. Fórizs Sándor 65. születésnapja tiszteletére. NKE Szolgáltató Nonprofit Kft., Budapest, 2016, 52-68. o.

26 Varga János: Határrendészeti vezetők felkészítése rendészeti környezetben. In: Gaál Gyula Hautzinger Zoltán (szerk.): A modernkori magyar határrendészet 110 éve. Magyar Rendészettudományi Társaság Határrendészeti Tagozat, Budapest, 2013, 289. o.

27 Fórizs Sándor: A mindig megújuló határrendészet. In: Varga János (szerk.): A határrendészeti tisztképzés negyedszázada. Dialóg Campus Kiadó, Budapest, 2017, 193-201. o.; Fórizs Sándor: A rendészeti változások iránya, tendenciái, mozgatórugói. In: Gaál Gyula - Hautzinger Zoltán (szerk.): A határrendészettől a rendészettudományig. Pécs, 2016, 31-41. o. http://pecshor.hu/periodika/XVII/forizs.pdf

28 Ritecz György: Határőrizet a rendszerváltástól napjainkig. In: Pósán László - Veszprémy László Boda József - Isaszegi János (szerk.): Örzők, vigyázzatok a határra! Határvédelem, határőrizet, határvadászok a középkortól napjainkig. Zrínyi Kiadó, Budapest, 2017, 642-673. o. 
vel-lélekkel végezhető. Az integrációban szerencsére tovább élhet, őrződhet, ápolódik az immár határrendészeti szolgálati ággá módosult határőrség szervezeti kultúrájának tetemes része. Utóbbi nagymértékben elősegítette annak idején a határőrség kiváló szintüre értékelt felkészülését Magyarország uniós és schengeni csatlakozásához. A schengeni csatlakozással a magyar államhatár mintegy fele azonnal jelképes, uniós belső határrá vált. Ez az illegális bevándorlás csökkenésével akkoriban meg is pecsételte a határőrség sorsát. Az integrációval a jól felkészült, tapasztalt határőr szakemberek fele kiáramlott. ${ }^{29}$ Az integrálódott határőrök szakmai felkészültsége, tapasztalata, szervezeti és munkakultúrája a rendőrség müködésére ${ }^{30}$ máig termékenyítőn hat, erősítve az egybeolvasztott szervezet egységét. Talán ezt is tükrözi az integráció tízéves évfordulója alkalmából, 2018. október 12-én, az ORFK-n az egykori határőrségi országos parancsnokság munkatársai számára szervezett nyugdíjastalálkozó.

Hautzinger Zoltán, az RTK dékánja üdvözletét tolmácsolva a határör értékek közül a máig müködő bajtársiasságot, a kimagasló szakmai együttmüködési készséget emelte ki. Majd hozzátette, hogy a határőr tradíciót, emlékeket, mindezek tudományos értékeit máig ápolja, kutatja, örökíti, a 2001-ben, az MHTT Határőr Szakosztályának Pécsi Szakcsoportja által útjára indított és évente megrendezett szakmai tudományostanácskozás-sorozat és az ennek előadásait tartalmazó konferenciakötet. Az interneten is elérhetöo ${ }^{31}$ kiadványsorból szépen vissza lehet követni, miként vélekedtek felelős szakemberek, tudományos kutatók a határőrizetről, idegenrendészetről, határrendészetről, az integrációról. Megjegyezte, hogy a határrendészeti tanszék nemcsak a határör hagyományok ápolását és továbbadását igyekszik folytatni, hanem az RTK tudományos tevékenységében is megőrizte a tanszékek közti vezető helyét. Balla József tanszékvezető az elhangzott köszöntőket Babits Mihály szavaival folytatta: „Múlt nélkül nincs jövö, s mennél gazdagabb a múltad, annál több fonálon kapaszkodhatsz a jövöbe!”

Farkas Johanna, a rendészettudományi kar pszichológus munkatársa elmondta egykori pszichológus kollégája, Virág László Fázol címü versét. Az egykori határőrök jogutód határrendészei előtt tisztelgő művészi előadását

\footnotetext{
29 Ritecz György: Az irreguláris migráció kezelés fejlődése, fejlődés-e? In: Gaál Gyula - Hautzinger Zoltán (szerk.): Pécsi Határőr Tudományos Közlemények XIX. Pécs, 2017, 287-292. o.

30 „A védelmi szervek (fegyveres erők, rendvédelmi szervek) professzionális beavatkozása, rátermettsége, kreativitása biztosíthatja a XXI. század legjelentősebb erőforrását a rendészet életképességének, eredményességének a jövőjét." Kovács, István: Is the prostitution a threat/danger to a country’s (national)security? Nemzetbiztonsági Szemle, Special Issue, 2017, 16. o.

31 www.pecshor.hu
} 
egy Márai-idézettel zárta: „, A barátság nem emberi kapcsolat, hanem szigorú erkölcsi törvény; alapvetö, erös és idötálló..."

Balázs László, az Országos Rendőr-fökapitányság határrendészeti föosztályvezetője a jelenlegi helyzet vázolása előtt köszönetet mondott a szervezőknek, , hogy lehetővé tették a mai napi kézfogásokat... Büszke vagyok ar$\mathrm{ra}$, hogy sok megjelent kollégával együtt dolgozhattam a végrehajtásban, később területi, vagy központi szinten. [...] A határörség jó iskolát jelentett, idötálló szervezeti kultúrát szívtunk magunkba. Ezek az alapok máig érvényesek minden területen!"

Felidézte, hogy az integrációt közvetlenül elökészítő közös, határőr-rendőr munkabizottságokban a határőrizeti szellemi-szakmai veszteség minimalizálására harmincöt különféle szervezetistruktúra-javaslat született. Akkoriban mindenki számára azonnal nyilvánvalóvá vált, hogy ezeket mennyire vette figyelembe az integrációról született döntés, azonban az integrált szervezetben is sikerült újra érvényesíteni a korábbi határrendészeti megoldások jó részét. Például a nemzetközi együttmüködési gyakorlat, készség, eredményeként a macedón, szerb, bolgár határrendészeti szervekkel kialakított munkakapcsolattal sikerült mintegy tizenháromezer, Magyarország irányába induló illegális bevándorlót elfogni. Emellett sikerült idehaza több új jogszabályt, eszközbeszerzést, határrendészetitechnológia-bevezetést kezdeményezni és keresztülvinni.

A határőrségnél elsajátított munkastílusnak az integráció után jócskán lett lehetősége kibontakozni, hasznosulni, mint kiderült a konferencia több előadásából is.

Az integráció traumatikus pillanatát Gáll József, a Szabolcs-SzatmárBereg Megyei Rendőr-fökapitányság határrendészeti szolgálatának vezetője idézte fel. „Egyik pillanatról a másikra a határőrök számára ismeretlen átláthatatlan rendörségi jelentési, fegyelmi-, adminisztrativ eljárási rendben találtuk magunkat! Egyik napról a másikra a Robotzsarut kellett alkalmazni. A régi határör szabályozók hatályukat veszitették, miközben a rendörségével együtt léptek életbe az új uniós és a szigorúbb schengeni jogszabályok. A teljesen új szervezeti rendszerben közülünk senki nem tudta pontosan helyét, szerepét az új szervezetben. Túl sok segitö kezet se kaptunk, hisz'a klasszikus rendöri feladatok épp' elég teendöt jelentettek addig is a befogadó szervezetnek. Megszünt a határőrségi önálló gazdálkodásunk, logisztikánk, a helyébe lépö új rendszer még nem müködött, és utána is annyi segitség, figyelem jutott nekünk, amennyi a megyei fökapitányság elsödleges közrendvédelmi, bünügyi, közlekedésrendészeti, stb. stb. feladatai után még maradt. De a fel- 
tételhiányos körülmények ellenére, a küszöbönálló schengeni ellenörzés miatt a határrendészeti elvárások egyre fokozódtak..." ${ }^{\prime 32}$ Felidézte, hogy a rendőrségbe integrált egykori határőrségi bünügyi felderítő szolgálat munkatársainak feladatai közt a határrendészeti információk biztosítása a fő teendőről a sokadik helyre szorult vissza. Viszont a schengeni külső határ őrizetét a legfőbb ügyészi állásfoglalás kiemelt jogi tárgyként kezeli, elvárva a Baltikumig húzódó keleti határokat vigyázó tagállamok legszigorúbb felelősségét... miközben a sok elvándorlás, leszerelés miatt a határrendész állomány is lényegében mintegy ötödére apadt. Mégis, az említett körülmények ellenére a rendszerben maradtak igyekeztek legjobb tehetségük, lehetőségeik szerint lelkiismeretesen garantálni a határbiztonságot ${ }^{33}$. Az integrációkor azonnal jelentkező problémák zömét - jórészt - az idő megoldotta, és a fennmaradók orvoslására szerencsére egyre érzékenyebb a rendőrség vezetése. Ilyen integrációs maradvány például, hogy míg egy hatvan-száz fôs rendőrkapitányság vezetés-irányítását egész törzskari állomány segíti, a határrendészetnél ugyanekkora állománnyal az állománytábla szerint egyetlen tisztnek kell elboldogulnia. De ez már nem a régi határörségi környezet, feladatrendszer, ehhez újak jöttek, mint például a bevezetett e-útdíj rendszerből rendőrségre ruházott teendök, illetve új nemzetközi feladatok.

Pozsgai Tamás, a Repülőtéri Rendőri Igazgatóság határrendészeti osztályvezetője az integrációról elmondta, hogy a repülőtéren szolgálatot teljesítő határrendészek számára bizonyos védelmet jelentettek a polgári repülés nemzetközi szabályai, követelményei. Itt az úgynevezett schengeni határellenörzés is pár hónap késéssel lépett életbe, de a 2017 decemberében még mintegy ezerfős határrendészeti igazgatóság állományából náluk is alig több mint kétszáz határrendész maradt. Mára viszont a Malév megszünése óta beálló változások közepette is sikerrel teljesítik megnövekedett feladataikat.

Bardócz Csaba, a Szegedi Rendészeti Szakgimnázium igazgatója is felidézte, hogy még az integráció első évében is kétéves OKJ-s határrendészeti képzés folyt. Itt összesen négyszázhatvan órában tanítottak határőrizetet, határforgalom-ellenőrzést, határvédelmet, szakmai gyakorlattal, mentorképzéssel együtt. Jelenleg az új rendszerben, az első két félév közrendvédelmi rendőrképzése után mintegy 216 órában kell átadni felelősséggel a korábbi

32 „A kezdeti években »a régi jogrend « már felbomlott, a helyébe lépő új még nem alakult ki megfelelően, ami némi bizonytalanságot keletkeztetett. Kovács István: „Olajozás”, szervezett bűnözés és prostitúció a 90-es években Magyarországon. Nemzetbiztonsági Szemle, 2015/1., 121. o.

33 Virányi Gergely: A biztonság-fogalomról, másként. In: Gaál Gyula - Hautzinger Zoltán (szerk.): Pécsi Határőr Tudományos Közlemények. Magyar Hadtudományi Társaság Határőr Szakosztály Pécsi Szakcsoportja, Pécs, 2012, 62. o. http://www.pecshor.hu/periodika/XIII/viranyi.pdf 
határrendész-szaktudást, -tapasztalatot és -tartást, amivel nem könnyü megbirkózni, a mind több, kiegészítő elvárásnak megfelelve. Napjainkban egyre nagyobb jelentőségü, és meghatározó szerepe van a határrendészeti továbbképzési rendszer müködtetésének. ${ }^{34}$

Balla József a képzési témához azzal csatlakozott, miszerint némi túlzással az elvárás szerint az a jó határrendész tiszt, aki mindenhez ért! A megrendelői igények maximális biztosítására határrendész tanácsadó testületet ${ }^{35}$ hoztak létre, amely a határrendészeti tanszék javaslattevő, véleményezö, döntés-előkészítő szerve, segíti a tanszékvezető tevékenységét az oktatási, tananyagfejlesztési, tudományos kutatási és fejlesztési kérdésekben. A rendőrség kötelékében eltelt egy évtized határőr hagyományainak továbbélése közül az új iránti fogékonyságra szolgáltatott határőr példákat Németh József, aki az MRTT Zala megyei csoportját vezette sokáig. Ezúttal a rendőrség tudományos tanácsának elnökeként $A$ kutatás-fejlesztés igénye a rendörségnél címmel tartott előadást. A kutatás-fejlesztés rendőrségi támogatásának jó példájaként Székely Zoltán a H2020, a SMILE és az iBorderCtrl projektet mutatta be közösen Zsákai Lénárddal, a Bács-Kiskun Megyei Rendőr-fökapitányság határrendészeti szolgálatának előadójával.

E legutóbbi, határrendészeti ihletésü tudományos tanácskozás mellett a pécsi konferenciák és tanulmánykötetek szintén nemcsak a múlt felidézésének és a jelen tudományos elemzésének szánnak teret, hanem a jövő technológiai lehetőségeivel, rendészetre gyakorolt hatásaival is foglalkoznak. ${ }^{36}$

\section{Epilógus helyett}

Önmagában az a törekvés, hogy a határőrségnél dolgozók és vezetők, valamint egyetemi oktatók és tudományos kutatók évente közösen vitatkoznak,

\footnotetext{
34 Molnár Henrietta - Balla József: A határrendészeti továbbképzés helyzetértékelése. Határrendészeti Tanulmányok, 2017/4., 4-27. o.

35 Balla József: A régi-új Határrendészeti Tanszéki Tanácsadó Testület, mint a megrendelői igények meghatározásának és támogatásának fóruma. Határrendészeti Tanulmányok, 2016/1., 66-83. o.

36 Zsigovits László: Globalizációból fakadó rendészeti kihívások a korszerű információtechnológia tükrében. In: Gaál Gyula - Hautzinger Zoltán (szerk.): Pécsi Határőr Tudományos Közlemények. Magyar Hadtudományi Társaság Határőr Szakosztály Pécsi Szakcsoportja, Pécs, 2014, 61. o. http://pecshor.hu/periodika/XV/zsigovits.pdf ; Zsigovits László: A jövő rendőre. In: Gaál Gyula - Hautzinger Zoltán (szerk.): Pécsi Határőr Tudományos Közlemények. Magyar Hadtudományi Társaság Határőr Szakosztály Pécsi Szakcsoportja, Pécs, 2017, 79-84. o. http://www.pecshor.hu/periodika/XIX/zsigovits.pdf
} 
jelzi a határőrség igényét saját hagyományaik megőrzésére, egyszersmind a müködés gyengeségeinek megismerésére. ${ }^{37}$

E megjegyzés évekkel a határőrség megszüntetése után is igaz. A határőrhagyományok, a rendőrségen belüli határrendészeti szolgálati ághoz kapcsolódó feladatok lelkiismeretes ellátása, a fejlesztésükre való törekvés tovább$\mathrm{ra}$ is a mindennapjaink része..$^{38}$

Talán ennek is köszönhetően a rendőrség felső és középvezetői között az egykori határőrtisztek jól kifejezik, képviselik a határőr-hagyományok értékeit napjainkban is.

Már az első konferencia szakmai tapasztalatai mellett megfogalmazódott az a gondolat, hogy a tudományos eszmecserét folytatni kell. Hiszen a határörség, illetve a határörök a rendvédelem számos területén jelen vannak, és igen sokrétü feladatot látnak el. ${ }^{39}$

A Pécsi Határör Tudományos Közlemények XX., jubileumi kötetében több szerző is szerepel, akik már az elsőben és azóta is többen, visszatérően publikáltak: Hautzinger Zoltán; Kovács Gábor; Ritecz György, Teke András, Zsigovits László. Mindannyian a határőrségnél szolgáltak...

37 Petrétei József: Beköszöntő. In: Gaál Gyula - Hautzinger Zoltán (szerk.): Pécsi Határőr Tudományos Közlemények. Magyar Hadtudományi Társaság Határör Szakosztály Pécsi Szakcsoportja, Pécs, 2006, 1. o.

38 Hautzinger Zoltán: i. m. 134. o.

39 Kovács Tamás: Egy nagykorúvá érett történet - a Pécsi Határőr Tudományos Közlemények történetéről. In: Gaál Gyula - Hautzinger Zoltán (szerk.): A határellenőrzés múltja, jelene és jövője. Pécsi Határőr Tudományos Közlemények Különszám, Pécs, 2017, 8. o. 